\title{
DEDICATION AND ACKNOWLEDGEMENTS
}

Genuine reform often requires swimming against strong currents of conventional wisdom and a refusal to pander to politically driven notions of what is and is not acceptable to think and do at the time. Governments often refuse to acknowledge and act on serious problems that undermine a nation's security - subsequently to be noted by even the most routine of historians to have been blind and foolish. The real test of statesmanship - no matter how unpopular the recognition of needed action may be among the blinkered paragons of contemporary conventional wisdom - is to note and act on the problems before they overwhelm the state.

For the wisdom and the moral courage to see and then act, the authors of this volume wish to recognize the memory of Col. John R. Boyd (U.S. Air Force). For the strength of character and extraordinary generosity of spirit that made this volume possible, the authors wish to thank and recognize Philip A. Straus, Jr., the founder of the Straus Military Reform Project of the Center for Defense Information, along with the additional support of the Stewart R. Mott Charitable Trust and its founder and guiding light, the late Stewart R. Mott, and the many private individuals who also contributed to the support of this work.

The authors also wish to thank the staff of the World Security Institute and the Center for Defense Information for their spirited support, diligent work and skillful professionalism in the completion of this book. Especially to be noted are Bruce Blair, Theresa Hitchens, Drew Portocarrero, Suzanne Ostrofsky, Ron Hinrichs, Deniz Ozdemir, Laura McHugh, Valerie Reed and Ana Marte. 